\author{
Wanda Jarząbek \\ Institute of Political Studies \\ Polish Academy of Sciences \\ ORCID 0000-0002-9778-6497 \\ wjarz@isppan.waw.pl
}

\title{
Compliance of Interests? \\ The Problem of the United Germany's Borders in Polish-French Political Relations between 1989 and 1990
}

The decisions taken by the Four Powers - the United States (US), the Soviet Union (USSR), Great Britain and France - in Potsdam concerned the conditions of occupation and did not defi nitively determine the future of Germany. The creation of two German states in 1949 became a source of further friction. The Western Allies tried to include the Federal Republic of Germany (FRG) in supra-state structures, the creation of which also resulted from the desire to maintain control over developments in that country. In 1951, the FRG became a member of the European Coal and Steel Community, and in 1955, of the North Atlantic Treaty Organization (NATO). The German Democratic Republic (GDR) was included in the structures of the Eastern bloc, the Council for Mutual Economic Assistance and the Warsaw Pact. The existence of this state was closely linked to the political and military power of the Kremlin. The integration of the FRG with the West and the GDR with the Eastern bloc did not close the road to the unifi cation of Germany. Nevertheless, it was impossible to carry this out during the severe Cold War confl ict and it was only possible to engage in concrete talks on this subject when the tension between the blocks eased. ${ }^{1}$

1 O. Bange, B. Lemke (eds),Wege zur Wiedervereinigung. Die beiden deutschen Staaten in ihren Bündnissen 1970-1990, De Gruyter, München 2013. 
The issue of a united Germany's borders was among the problems where no legally binding decisions were made after 1945. In the absence of a treaty settlement, political declarations and the position taken by the Four Powers gained particular importance. After the so called Paris Agreements abolished the occupation status, the countries retained their rights and responsibilities in relation to Berlin and Germany as a whole, including the unification of Germany and the conclusion of a peace treaty. The division of Germany was conducive to France maintaining its superpower status. However, French and German politicians were aware that the antagonism between their states and societies was not conducive to the development of cooperation on the continent. The signing of the Élysée Treaty in 1963 was to create an institutional basis for cooperation. Since the 1980s, Franco-German cooperation has become extremely important for determining the directions of European integration. ${ }^{2}$ This affected France's attitude to the so-called German problem. ${ }^{3}$ At a political level, Germany's right to reunification was not questioned, although this was not anticipated to happen quickly in the geopolitical reality of that time. ${ }^{4}$

The main aim of this article is to show the conduct of Polish-French talks at the time of German unification. That time collaboration between Warsaw and Paris went beyond the level of contact with the other Big Powers.

The article is based mostly on primary sources, interviews and also published documents.

\section{France and the Polish-German Border}

By the decision of the Potsdam Conference, the western border of Poland was moved to the Oder-Neisse line. Admittedly, from a formal point of view, the borders were to be finally approved in a 'peace settlement', but these territories were given over to the Polish administration (meaning that they were included in the Polish administrative system) and were excluded from the occupation regulations in force. France repeatedly hinted that it saw the unification of Germany within the borders of the two existing German states. This primarily emerged from the interests of France but was also in line with those of Poland. Paris also assured Warsaw of its support for the Oder-Neisse border. In general, Polish-French relations were quite lively by the standards of relations between countries on the opposite sides of the Iron Curtain. ${ }^{5}$

In 1958, contrary to the opinion of Foreign Minister Maurice Couve de Murville, President Charles de Gaulle engaged in bilateral talks with Warsaw regarding the

\footnotetext{
2 V. Guérin-Sendelbach, Ein Tandem für Europa? Die deutsch-französische Zusammenarbeit der achtziger Jahre, Europa Union Verlag, Bonn 1993.

3 On difficult Franco-German relations see: G.-H. Soutou, L'alliance incertaine. Les rapports politico-stratégiques franco-allemandes, 1954-1996, Fayard Paris 1996; R. Picht, V. Hoffmann-Martinot, R. Lassare, P. Theiner, Fremde Freunde. Deutsche und Franzosen vor dem 21. Jahrhundert Piper, München 1997.

4 F. Bozo, Mitterrand, the End of the Cold War and German Unification, Berghahn, New York-Oxford 2009; T. Schabert, Wie Weltgeschichte gemacht wird. Frankreich und die Deutsche Einheit, Klett-Cotta, Stuttgart 2002.

5 D. Jarosz, M. Pasztor, Polish-French relations 1944-1989, trans. A. Shannon, Peter Lang, Frankfurt am Main 2015.
} 
issuing of a public statement about Paris's recognition of the Oder-Neisse border as final. In return, the communist government of Poland was not to recognise the Algerian émigré government supported by the USSR. ${ }^{6}$ The Berlin crisis slowed down further talks, but at a press conference at the Élysée Palace on 25 March 1959, de Gaulle spoke in favour of the reunification of Germany, yet pointed out that he would support merging the two parts into one country provided that the current borders in the west, east, north and south were not questioned. The communist authorities of the Polish People's Republic rightly considered this statement as an indirect recognition of the Oder-Neisse border, although President de Gaulle did not mention this name. ${ }^{7}$ Warsaw tried to make France repeat its position and even take further steps in manifesting support for the border. The French side also proved willing to make symbolic gestures. For example, during his visit to Poland in 1967, General de Gaulle went to Zabrze and spoke about the Polish character of Silesia. ${ }^{8}$ French diplomats also talked about the border with their German counterparts, indicating that it was recognised as legitimate. It was repeatedly pointed out that France had already taken the floor on this matter and did not change its mind. France's position was important during the Polish-West German talks regarding the signing of the Treaty on the Basis for Normalisation of Mutual Relations in 1970. ${ }^{9}$ During bilateral consultations, the director of the Political Department, J. de Beaumarchais, assured Warsaw that France also supported the recognition of the border in talks with West Germany. ${ }^{10}$ In France, maintaining the presence of the Four Powers in Berlin was considered to be particularly important for maintaining the powers' rights as regards the German problem. ${ }^{11}$ In the case of borders, it was believed that the situation of the FRG-GDR border, the recognition of which would mean consolidating the division of Germany, was different to the Oder-Neisse border, which could be considered final ('la reconnaissance du caractère définitif de la frontière Oder-Neisse pourait être envisagée'). ${ }^{12}$ France played a fairly important

\footnotetext{
6 See: W. Jarząbek, "'Z Polską nie robię żadnych przetargów...’ Gen. Charles de Gaulle, granica na Odrze i Nysie Łużyckiej i kryzys algierski”, Dzieje Najnowsze 1999, No. 3, pp. 159-169.

7 Eadem, "W sprawach niemieckich nasz głos musi mieć swą wagę... Problem niemiecki w polskiej polityce zagranicznej w latach 1956-1958”, Dzieje Najnowsze 2001, No. 2, pp. 103-129. 8 Eadem, "Rozmowa Charlesa de Gaulle’a z Władysławem Gomułką w czasie wizyty generała w Polsce we wrześniu 1967 r.”, Dzieje Najnowsze 2000, No. 4, p. 147 et seqq.

9 Eadem, Polska Rzeczpospolita Ludowa wobec polityki wschodniej Republiki Federalnej Niemiec w latach 1966-1976. Wymiar dwustronny i międzynarodowy, Instytut Studiów Politycznych PAN, Warszawa 2011, p. 243 et seqq.

10 Archiwum Ministerstwa Spraw Zagranicznych (further AMSZ), Dep. IV, z. 28/76, w. 4, Pilna notatka z konsultacji polsko-francuskich z 2-3 lutego 1970 r., A. Willmann; Archives du ministère des Affaires étrangères, (further AMAE), Europe 1966, - 1970, Pologne, v. 2501, Consultations politiques franco-polonaises 2 et 3 février 1970 à Varsovie, (meeting 2.02.). AMAE, Europe 1966, - 1970, Pologne, v. 2501, a dispatch to French embassies on Polish-French consultations in Warsaw, 14 Feb. 1970.

11 AMAE, Europe 1966-1970, RFA, v. 1547, a dispatch from the French embassy in London to Paris, 7 April 1970.

12 AMAE, Europe 1961-1970, RFA ,v.1547, Note. Implications possibles pour les intérêts des trois puissances de la politique d'ouverture à l'Est du Gouvernement fédéral, 13 March 1970.
} 
role in torpedoing the plans of West Germany, which wanted Western powers to make declarations during the Polish-German talks of 1970 that Bonn did not have the right to speak on the shape of Germany's borders, that is, it could not recognise the Oder-Neisse border. Consequently, no joint statement was issued by the powers, and the statements of France, the US and Great Britain did not question the validity of the Polish-German Treaty of 6 December 1970. The Treaty on the Basis for Normalisation of Mutual Relations between the People's Republic of Poland and the FRG recognised the Oder-Neisse border as the western border of Poland. Soon after its signing, however, voices began to appear in West Germany stating that this was not the final recognition of the border. In December 1971, the West German government announced a Memorandum, in which it was noted, inter alia, that the West German government had signed it on its own behalf and that the agreement could not bind the future government of a united Germany. There was no mention in the Memorandum, however, that the parties had no territorial claims against one another and would not make them in the future either.

Admittedly, when the issue of German reunification became commonplace, it was difficult to find supporters of border changes among European countries, including those responsible for the reunification of Germany. But not all changes in Europe were made by decisions taken in diplomatic salons. At that time, many of them resulted from bottom-up aspirations and the disintegration of the USSR began. That is why Warsaw wanted no legal doubts about the nature of the Oder-Neisse border in Polish-German bilateral relations when a new political order was born in Europe in 1989. Pursuant to the legal position of West Germany, this country treated the Potsdam Agreement as res inter alios acta and therefore not binding in West Germany, hence the issue of the lack of peace settlement announced therein was on the agenda. ${ }^{13}$

\section{France and Poland in the Face of Events in Germany}

The reactions of France and Poland to the peaceful revolution in the GDR and the launch of the unification process were a derivative of their relationship with the FRD.

In 1989, efforts to improve tense relations between Warsaw and Bonn were intensified. Chancellor Helmut Kohl's visit to Poland was to become a symbol of an opening in mutual relations. Due to the fall of the Berlin Wall, the visit was interrupted, and the chancellor returned on 12 November. During the first round of talks on 9 November, Polish Prime Minister Tadeusz Mazowiecki wanted to talk about the Oder-Neisse border ${ }^{14}$. Although the chancellor said that West Germany had no territorial claims against Poland, he also explained that, 'No German government can recognise the Oder-Neisse border today on behalf of the whole of Germany, which will only be formed in the future ... The issue of the Oder-Neisse border cannot be raised

13 J. Barcz, Udziat Polski w konferencji '2+4'. Aspekty prawne i proceduralne, Polski Instytut Spraw Międzynarodowych, Warszawa 1994, pp. 20-21.

14 Zapis rozmowy w „cztery oczy” Premiera Mazowieckiego z Kanclerzem Kohlem, notatki z 9, 10 i 14 listopada 1989 r., in: Polska wobec zjednoczenia Niemiec 1989-1991. Dokumenty dyplomatyczne, ed. W. Borodziej, Warszawa 2006, p. 158 et seqq. 
every day'. ${ }^{15}$ In the talks held on 14 November, when referring to the legal position of the FRG, Kohl expressed concerns with Mazowiecki's proposal that in the planned 'Joint statement' of both heads of government, the part about the border should include a fragment from the Bundestag's resolution of 8 November 1989. This also mentioned that the "wheel of history could not be undone and that the Polish people should know that their right to live within safe borders would not be questioned by the Germans through territorial claims either now or in the future'. This statement repeated a fragment of the Minister of Foreign Affairs, Hans-Dietrich Genscher's speech at the United Nations forum on 27 September $1989 .{ }^{16}$ Polish politicians remained disgusted by Germany's reluctance to make an unequivocal declaration on the Oder-Neisse border. As the memories of the main German actors suggest, the disgust was imperceptible to them. ${ }^{17}$

In this situation, Chancellor Kohl's announcement of a 'Ten-point reunification plan' for Germany raised concerns in Warsaw. As observers of the events in Poland put it at that time, it lacked the eleventh point referring to the border. ${ }^{18}$ Other countries also perceived this declaration as a desire to start the process of unifying Germany under German conditions. ${ }^{19}$

France intently watched reactions to the fall of the Berlin Wall, aware of its importance for the international situation. ${ }^{20}$ The fall of the wall and, above all, the ten points proposed by Kohl became the reason to start work on closing the German problem. The unification of Germany required the regulation of political and military issues, such as the problem of borders, status of Berlin and other problems resulting from the termination of rights and responsibilities of the four powers. France did not want this to upset its position in Europe. ${ }^{21}$ France, as a power responsible for the unification of Germany, was not consulted about Kohl's ten point declaration. The independent announcement of Germany's position and Kohl's visit to the GDR on 19 December allowed the chancellor to gain a favourable position internally and internationally. ${ }^{22}$ In France, this was a signal to activate diplomacy. France expected the process of Germany's unification to take place under the control of the four powers

15 Ibidem, p. 162.

16 D. Bingen, Polityka Republiki Bońskiej wobec Polski. Od Adenauera do Kohla 1949-1991, Znak, Kraków 1997, pp. 241-242.

17 H. Kohl, Pragnąem jedności Niemiec, Świat Książki, Warszawa 1996, H. Teltschik, 329 dni. Zjednoczenie Niemiec w zapiskach doradcy kanclerza, transl. R. Drecki, M. Struczyński, Oficyna PANDA, Warszawa 1992.

18 In Warsaw, it was perfectly understood that with the announcement of this plan by the incumbent chancellor, West Germany assumed political responsibility for the process of unifying Germany, which gave an additional shade to all government declarations, as A. Hajnicz wrote in: idem, Ze soba czy przeciw sobie. Polska - Niemcy 1989-1992, Presspublica,Warszawa 1996, p. 79.

19 S. Szabo, The Diplomacy of German Unification, Palgrave Macmillan, New York 1992.

20 F. Bozo, Mitterrand..., p. 111 et seqq.

${ }^{21}$ H.-K. Bender, Mitterrand und die Deutschen. Die Wiedervereinigung der Karolingen, Bouvier, Bonn 1995, s. 71; Ch. Hacke, Die Aussenpolitik der Bundesrepublik Deutschland. Von Konrad Adenauer bis Gerhard Schröder, Ullstein, Frankfurt am Main 2003, p. 369.

22 AMAE, Europe 1986-1990, v. 6124, Note sur le processus d'unification allemande et le nouvel ordre de sécurité en Europe (A. Carton) 02 Jan.1990. 
and did not want disputable issues, such as those concerning the borders, to be left to the parties concerned, that is, Germany and Poland. ${ }^{23}$ Paris desired the unification of Germany to take place according to the principles that would not weaken France's position in Europe. It was also important that Germany would not lose interest in European integration, considered also in terms of national security. The integration was treated as a means to avoid a situation in which Germany would decide to seek a different path for itself than the close alliance with Western countries. ${ }^{24}$ Since autumn 1989, more intensive study work was conducted at the French Ministry of Foreign Affairs regarding the impact of the process of Germany's unification on the new European order, mainly in the context of security policy. One of the elements of the work undertaken at that time was gathering material about German borders, primarily in a legal context. The studies referred also to ethnic and historical arguments. ${ }^{25}$

At a political level, French decision-makers were in favour of respecting the rights of both Germans and the occupying powers and searched for an adequate solution in accordance with international law and existing obligations. This position was presented in official declarations. On 12 December 1989, Foreign Minister Roland Dumas spoke to the National Assembly for the right of the German people to self-determination. He indicated that the rights of Germans should be respected and that other European countries should also agree to the changes. ${ }^{26}$ During his visit to Kiev in December 1989, the President of France spoke on the legitimacy of maintaining the sovereignty of the GDR and respecting European balance, and expressed his support for evolutionary change. This was received by some observers as seeking help from the USSR in blocking reunification behind Kohl's back. ${ }^{27}$ According to some researchers, Mitterrand believed that Gorbachev would not agree to the unification of Germany. ${ }^{28}$ To the dissatisfaction of Bonn, Mitterrand also visited the GDR. ${ }^{29}$ The French side was aware that the process had already been launched and wanted to clearly indicate the French position on key issues. On 12 December 1989, French Foreign Minister Roland Dumas had already declared the inviolability of the borders in the National Assembly. Aware of French concerns, Chancellor Kohl stated on 18 January 1990 during his visit to Paris that Germany's unification was not connected with the change of the Polish western border. ${ }^{30}$ Nevertheless, Paris did not consider this statement as exhausting the subject. Dumas also took up the issue of borders during his visit to Berlin on 1 March 1990

23 F. Bozo, Mitterrand..., 212 et seqq.

24 Such motives of French policy are also pointed out by H. Vedrine in idem, Les Mondes de François Mitterrand. A l'Élysée, 1981-1995, Fayard, Paris 1988, p. 416.

25 AMAE, Europe 1986-1990, v. 6135, L'Allemagne, ses frontières et la système de sécurité en Europe.

26 H. Teltschik, 329 dni..., p. 66.

27 F.- O. Giesbert, François Mitterrand: die Biographie, Propyläen, Berlin 1997, p. 497.

28 V. Guérin-Sendelbach, Wiedervereinigung, in: R. Picht, V. Hoffmann-Martinot, R. Lassare,

P. Theiner, Fremde Freuden.Deutsche und Franzosen vor dem 21. Jahrhundert, Piper, München 1995, p. 149.

29 H. Teltschik, 329 dni..., p. 81. H. Kohl, Pragnątem jedności... .

30 H. Teltschik, 329 dni..., p. 94. 
stating that: 'bare statements, even the most solemn, are not sufficient. Such important matters require treaty regulations subject to ratification'. ${ }^{31}$

At that time, Warsaw tried to develop a diplomatic campaign to present its interests related to the reunification of Germany, including the border. During Mazowiecki's talks in London on 12 February, Margaret Thatcher said: '... we must act quickly because more and more people say that unification is good. Hence, it must be said openly that the price of unification is the recognition of the borders by Germany. ${ }^{32}$

During the Open Sky Conference in Ottawa on 13 February 1990, the $2+4$ format (two German states and the Four Powers) of talks on German reunification was accepted. The French side wanted the conference to be called $4+2$. This last form was consistently used in French documents but was not adopted by other countries. The Polish Minister of Foreign Affairs, Krzysztof Skubiszewski, requested the conference's agenda to also include the interests of the neighbours and suggested adding the formula 'including the issues of security of neighbouring countries' in the documents specifying the scope of talks, which actually happened. ${ }^{33}$ In identically sounding letters addressed to the leaders of the four powers, Prime Minister Skubiszewski stated: In the Federal Republic of Germany, the exclusivity of the future peace treaty to regulate this border (the Oder-Neisse border, W. J.) has been repeatedly emphasised. ... I declare that Poland is ready to participate in the work on the treaty. However, for reasons beyond Poland's control, work on the peace treaty is either currently not taken into account or is postponed to an indefinite moment after the unification of the German nation, which gives some forces the opportunity to consider the Polish-German border as an open matter. We cannot agree for this situation to continue after the reunification of Germany. ${ }^{34}$ Mazowiecki proposed to sign a treaty confirming the final character of the existing border, initialled by Poland and the two German states before reunification and signed after reunification, and announced the submission of a draft treaty. $\mathrm{He}$ also found it necessary for Poland to participate in discussing the external aspects of unification. He also explained that Poland 'does not seek identical status with any of the four powers or with either of the two German states. ${ }^{35}$ However, the letter was received differently: in the US it was understood as an expression of Poland's aspiration to be the fifth power. ${ }^{36}$ German diplomats in Warsaw also indicated that Poland was willing to join the unification talks to the full extent. ${ }^{37}$

31 M. Tomala, Zjednoczenie Niemiec. Reakcje Polaków, Wydawnictwo Adam Marszałek, Warszawa 2000, p. 107.

32 Roboczy zapis rozmowy Prezesa Rady Ministrów Tadeusza Mazowieckiego z premierem Wlk. Brytanii i Płn. Irlandii panią Margaret Thatcher, London 12 February 1990, in: Polska wobec..., p. 197.

33 Komunikat z Ottawy, 13 February 1990 in: J. Barcz, Udziat Polski..., p. 113.

34 List Prezesa rady Ministrów RP Tadeusza Mazowieckiego skierowany do Prezydenta Republiki Francuskiej Françoisa Mitteranda, in: J. Barcz, Udział Polski..., pp. 114-115.

35 Ibidem, p. 116.

36 Cf. Ph. Zelicow and C. Rice, Germany United and Europe Transformed. A Study in Statecraft, Harvard University Press, Cambridge 1995, p. 216 et seqq.

37 See, for example: Drahtbericht des Botschafters Knackstedt, Warszawa, 19 February 1990 in: Die Einheit, Das Auswärtige Amt, das DDR-Außenministerium und der Zwei-plus-Vier-Prozess, Vandenhoek \& Ruprecht, München-Berlin 2015, pp. 276-278. 
The German side informed France (as well as Great Britain and the US) that Warsaw demanded the signing of a peace treaty with Germany not only because it was interested in obtaining final confirmation of the border but also because it wanted to receive reparations from Germany. French diplomats passed it on to their Polish interlocutors. ${ }^{38}$ Studies conducted by the French side indicate that this possibility was taken seriously also because of the fact that Warsaw was in a difficult economic situation. On the other hand, French diplomats tried to explain the Polish position to the German side. They pointed to the sources of Polish sensitivity and informed Germany about supporting the Polish postulate regarding consultation on the external aspects of the unification. ${ }^{39}$ The French side also noticed that there were different approaches in West Germany. For example, they saw that the Minister of Foreign Affairs, H-D Genscher, considered Chancellor Kohl's proposals from 2 March awkward. Namely, Kohl accepted for the first time the very concept of signing a bilateral Polish-German treaty on the border, but on the condition that Poland would renounce reparation and recognise the rights of the German minority in Poland. The French side was aware that Mazowiecki's government gave minorities a free hand in the development of teaching, publication and creating cultural associations. The Polish side explained that it sought compensation for forced labourers (not reparations). ${ }^{40}$ Many of the expectations Warsaw addressed to Paris could have become reality because they were in line with the French concepts of the unification process. This primarily included support for Warsaw's position regarding the border because Paris did not intend to depart from its previous assurances that it supported the final nature of the Oder-Neisse border. The French side also did not oppose the Polish postulate to participate in some form in the $2+4$ conference. France was also against creating an additional formula for consultations exclusively for Western countries and West Germany or conducting consultations only in the NATO framework before the $2+4$ conference, although it agreed to regularly inform them on the developments. The concept of signing a bilateral treaty regulating the nature of the border was also supported by France. Naturally, the details needed to be agreed and France's position crystallised during the talks. Warsaw started to join high-level talks in France. Initially, Warsaw thought of Minister Skubiszewski's visit to Paris and sending a special representative authorised to participate in the talks about the $2+4$ process. ${ }^{41}$ However, seeing the rapid development of the situation after the Ottawa meeting, Poland began to seek a visit at the highest level. The Polish side also wanted the visit to Paris to take place before the planned visit of Tadeusz Mazowiecki to the US at the end of March (it took place on 21 March). Paris understood this and the Prime Minister's visit was scheduled for 9 March. In the meantime, Chancellor Kohl's attitude towards talks about the border began to change, although he officially still adhered to West Germany's legal position that only a united Germany could decide on the border. ${ }^{42}$ Neither Gorbachev (talks on 10 February), Mitterrand (talks on 15 February) nor Bush

\footnotetext{
AMSZ, Dep. III, z. 35/94, w. 2, a dispatch from Paris of 3 February 1990.

T. Schabert, Wie Weltgeschichte gemacht wird, p. 470.

AMAE, Europe, v. 6462, Note de synthèse, 7 March 1990.

AMAE, Europe, v. 6462, Harel's dispatch of 19 February 1990.

2 F. Bozo, Mitterand..., p. 222.
} 
(talks on 24 February) could be persuaded to exclude the issue of the border from the unification talks. Moreover, a coalition partner of the CDU-FDP, Minister of Foreign Affairs H-D Genscher and the opposition party SPD expressed their support for a clear position on the border.

During Kohl's visit to Paris on 15 February 1990, the President of France said that from a legal point of view, the border should actually be recognised after the reunification but it should be confirmed at the political level beforehand. ${ }^{43}$ This was also the spirit in which Minister Dumas spoke publicly during his visit to Berlin. In this situation, it is hard to consider the Bundestag's resolution on the border on 8 March accidental. This was on the eve of the official visit of President Jaruzelski and Prime Minister Mazowiecki in Paris. Rather, it could be seen as an expression of the fact that Bonn was aware of the unchanging position of Paris. The French position was communicated to Warsaw. Mitterrand also noted that France and Germany had friendly relations. The French side confirmed that, in its view, the unification of Germany would not be possible without confirming that the border was final. ${ }^{44}$ In his note from the visit, Skubiszewski wrote: 'France is strongly in favour of the inviolability of the Oder-Neisse border and will use all means at its disposal to push this position' ${ }^{45}$ Warsaw also gained support for its goal, which was to give the recognition of the border the nature of a treaty, and expressed its support for the fact that it would also receive guarantees from the four powers, yet it reserved the right to comment on the nature of these guarantees in the future. France also supported Poland's efforts to participate in the part of the $2+4$ talks concerning Poland's borders and external security. The French side was also concerned with the pace of reunification yet it was quite convinced that at least the border issues would be resolved and, presumably, it perceived the German policy as a kind of game aimed at internal interests. ${ }^{46}$ President François Mitterrand demonstrated his support for the Polish side's position by participating in a joint press conference with Polish guests and by saying that the French stance went further than the Bundestag declaration. He also expressed the view that the four powers should take responsibility for legally closing the border issue, which was taken as support for the Polish concept of initialling a border treaty before reunification, and even as support for the concept of extending the rights of the powers after the reunification of Germany until the border problem was legally solved. ${ }^{47}$ France believed that it made no sense to dissuade Warsaw from trying to implement this concept. In a telephone conversation, Mitterrand also informed Chancellor Kohl that France shared the Polish view on the

\footnotetext{
$43 \quad$ Ibidem. p. 223.

44 Archives Nationales (AN), 5AG4/CDM 34, Notes from the talks.

45 Notatka informacyjna $\mathrm{z}$ oficjalnej wizyty prezydenta W. Jaruzelskiego i prezesa Rady Ministrów T. Mazowieckiego we Francji (9.03.1990), in: M. Tomala, Zjednoczenie...

46 W. Jarząbek's talks with Political Director of the French Ministry of Foreign Affairs B. Dufourcq and Sophie Caroline de Margerie, advisor to the President of France, Paris, June 2006.

47 H. Teltschik, 329 dni..., p. 141. According to the German ambassador in Paris, President Mitterrand appeared as 'Defensor Poloniae' and did not mention a word about the changing nature of cooperation between Poland and Germany. F. Pfeffer, Ein Amt und eine Meinung. Botschaftef in Polen und Frankreich, Societäs Verlag, Frankfurt am Main 2006, p. 347.
} 
need to start talks on the border treaty before reunification. Responding to Kohl's allegations, he explained that the French position was not the same as the Polish one. ${ }^{48}$ In his memoirs, Kohl wrote that after talking to the French leader, he had the impression that a small entente had come alive and complained that German feelings were not taken into account. ${ }^{49}$

On 23 March, Ambassador Fijałkowski talked with the Secretary General of the French Ministry of Foreign Affairs. Warsaw made efforts to ensure that the meeting on technical issues of reunification, planned at the level of general directors, would take place in Warsaw, but West Germany objected this symbolic inclusion of Warsaw. Warsaw continued talks with France and consultations were held with the participation of legal experts, Jerz Barcz on Polish side ${ }^{50}$. French diplomats watched the discussions and statements in Germany. For example, they noted that the President of the Bundestag, Rita Süssmuth, supported Germany's recognition of the Polish-German border before signing a peace treaty. When assessing the statements of German politicians, it was noted that most of them were guided by calculations focused on internal relations, not international opinions. It was also recalled that many people in Germany saw the Eastern Treaties as a temporary solution, rather than documents ultimately regulating border matters.

For this reason, the Directorate of Political Affairs of the French Ministry of Foreign Affairs asked the Legal Department about the methods that could be used to 'crystallise the German recognition of the Oder-Neisse border' ['Cristalliser la reconnaissance allemande de la frontière Oder-Neisse']. ${ }^{51}$ Various solutions were considered in the Legal Department. References were made to the records of talks in Yalta and Potsdam constituting the post-war order in Europe, as well as to the arrangements determining West Germany's status after the unification of the occupation zones. It was emphasised that in accordance with Article 7 of the so called General Treaty (Convention on Relations Between the Three Powers and the Federal Republic of Germany of 1952, ratified on 23 October 1954), the peace settlement should be freely negotiated between Germany and its former enemies. This meant that it did not have to (or should) be solely determined by the Four Powers. It was possibly legitimate to include Poland in talks on matters concerning the country. Various options for implementing the 'peace settlement' were considered. It was indicated that it would be best to include everything in a peace treaty. Nevertheless, it was pointed out that Germany was hesitant to sign such a treaty. It was noted that, in accordance with international law, a united Germany should take over the obligations arising from previously signed treaties and would be a successor state. It was mentioned that there was a legal possibility of using a bilateral option, that is recognising that Poland and Germany would negotiate the border agreement after the suspension of the Four Powers' rights.

In May 1990, trilateral talks began between the Polish side and both German states. There were three meetings on 3,18 and 29 May. West Germany did not change its

\footnotetext{
48 AN, 5AG4/CDM 33, A note from the talks.

49 H. Kohl, Pragnątem jedności...., pp. 190-193.

50 W. Jarząbek's talk with Professor Barcz, May 2019.

51 AMAE, Europe 1986-1990, v. 6135, A note on the Oder-Neisse border, 9 April 1990.
} 
view of initialling the treaty before reunification, citing legal problems and a lack of competence to determine the text of the treaty. It also did not want further meetings in this form ${ }^{52}$ Warsaw announced the deadlock in the Polish-German-German talks during meeting with Bertrand Dufourcq (the French chief negotiator on German reunification) on 14 May in Paris. ${ }^{53}$ Polish side was represented by Director of the Department of European Problems Professor Jerzy Sułek and Jerzy Barcz (expert on legal matters). The French side emphasised that it found it important for the powers to play a key role in decision making, but Poland would be invited to present its opinion. Sułek said that Poland was interested in real reconciliation with Germany - as was the case with France - and did not seek cooperation with France against Germany. However, because of the situation, it still wanted the border agreement to be initialled before the reunification and signed after the reunification. Poland was not satisfied with the German proposal, that is issuing an agreed declaration by both German parliaments and notifying the declaration in Warsaw. He explained that Warsaw did not even care about a formal signature and that its intention was to work out a bilateral treaty before the reunification so that Poland would not be left with the problem. Dufourcq also believed that guarantees in line with international law were necessary, but he did not prejudge their form. Warsaw was afraid that parliamentary declarations might also not be recognised after the reunification by the German government or parliament and, additionally, they had no legal force. Minister Skubiszewski handed this opinion over to the French ambassador after the Bundestag and the People's Chamber issued a declaration on 22 June 1990. ${ }^{54}$

The Polish diplomatic offensive to make Warsaw join the $2+4$ conference table was a partial success. On 4 July, a preparatory meeting of political directors of the Ministry of Foreign Affairs was held in Berlin before the meeting of the Paris $2+4$ conference with the participation of Poland. Warsaw proposed, above all, to supplement the first point of the draft document prepared for the Paris meeting with the statement that 'these borders (German borders after the reunification, W. J.) are the basic component of the peace settlement in Europe'. By this expression (peace settlement) Warsaw wanted to refer to the wording used in Potsdam Agreement. The Polish side also suggested supplementing the second point of the draft announcing the confirmation of the border by a united Germany and Poland in the form of international treaty with an extension that the border treaty "will enter into force at the latest on the day of entry into force of the "final settlement". ${ }^{55}$ Warsaw also wanted the fourth point (in which both German states undertook that the constitution of a united Germany would not contain provisions contrary to the principles mentioned earlier in the document) to be supplemented with the statement that this principle would relate to 'the other legal provisions of a united Germany' as well. ${ }^{56}$

\footnotetext{
52 W. Jarzabek's interview with the German Foreign Minister M. Meckel, Berlin, September 2019.

53 AMAE, Europe, v. 6457, a dispatch, 16 May 1990.

54 AMAE, Europe, v. 6135, a dispatch from Warsaw of 25 June 1990.

55 AMSZ, Dep. IV, 15/94, w. 1, „Zasady uregulowania w sprawie granic” (thumaczenie) wraz z polskimi propozycjami uzupełnień jako załącznik do: Notatka informacyjna nt. udziału RP w rozmowach „2 + 4” na szczeblu roboczym, J. Sułek, 10 July 1990.

56 Ibidem.
} 
The French delegation and East Germany suggested linking the entry into force of the border agreement with the expiry of the Four Powers' rights. ${ }^{57}$ Dufourcq arrived in Warsaw on 12 July to inform about the results of talks between the Allies and Germany in London and Houston. Skubiszewski agreed for the border treaty to be signed after the reunification and informed that the Germans refused all, even informal, talks. He indicated that Poland expected the Polish-German border treaty to be part of the peace settlement. ${ }^{58}$

The meeting of the $2+4$ and Poland foreign ministers took place on 17 July 1990 in Paris. They accepted some Polish postulates and Warsaw resigned from some of them. ${ }^{59}$ The first paragraph 'Rules on the settlement of the matter of borders' contained the provision: 'Confirmation of the final nature of borders is an important part of the peace order in Europe'. The term 'peace order' was used instead of the 'peace settlement' contained in the Potsdam Agreement and proposed by Warsaw. ${ }^{60}$ The German foreign minister added to the records of the meeting that the border treaty would be signed as soon as possible after the reunification, and the four allied powers confirmed that the borders of a united Germany would be final. Minister Skubiszewski added that in the opinion of the Polish government this statement did not constitute a guarantee of borders by the Four Powers. ${ }^{61}$ Warsaw did not want the border to have additional guarantees beyond those agreed with Polish participation.

The Treaty between the Federal Republic of Germany and the Republic of Poland on the confirmation of the frontier between them was signed on 14 November 1990 in Warsaw. The Treaty between the Federal Republic of Germany and the Republic of Poland on Good Neighbourhood, Friendship and Cooperation was signed on 17 June 1991 in Bonn.

\section{Conclusions}

At first, France did not expect the problem of German reunification to be on the agenda so quickly as it happened due to changes in Central and Eastern Europe.

When Paris realised that the German government attempted to take control of the unification process, it decided to emphasise the need to stick to the post-war obligations which entrusted a special role to the Four Powers. France was interested in stability in Europe and wanted to avoid a situation that could lead to further antagonisms. For this reason, Paris was against borders' changes. Since the creation of two German states,

\footnotetext{
57 Ibidem, Notatka informacyjna ...

58 AN, 5AG4/CDM 34, dispatch from Warsaw of 12 July 1990.

59 AMSZ, Dep. IV, z. 15/94, w. 1, depesza K. Skubiszewskiego z Paryża do T. Mazowieckiego, 18 July 1990.

${ }^{60}$ Zasady uregulowania sprawy granic przyjęte podczas spotkania paryskiego, in: J. Barcz, Udziat Polski..., p. 165. Zapis z przebiegu dyskusji ministrów spraw zagranicznych „2+4” z udziałem min. K. Skubiszewskiego 17 lipca 1990 w Paryżu godz. 15.30 - 18, in: Polska wobec..., pp. 400-408. The French position: AN, 5AG4/CDM 34, Note operationnelle, 13 July 1990.

61 The minutes of the meeting were sent by the French side to the Polish side. The original and translation can be found in: J. Barcz, Udziat Polski..., pp. 166-167.
} 
there was a belief in France that the reunification should take place only within the borders of the both existing states. Poland was of a similar opinion. The durability of the Oder-Neisse border was considered consistent with the raison d'état of both countries - France and Poland. For the Mazowiecki's government obtaining the final recognition of the border was important also due to the social moods. The German question was an important tool of power legitimisation in Poland. People expected the government to solve all borderline controversies in a legal way at the time of German reunification. Indeed, France cooperated with Poland and supported some Polish demands, but this was a consequence of the French authorities implementing the French vision of the European order. Kohl's adviser, H. Teltschik's remark that 'France always stands on the side of Poland when there are problems with Germany', which shifted Polish-French cooperation to the level of traditional behaviour or sentiment, does not reflect the essence of this kind of compatibility of interests. ${ }^{62}$

\section{Abstract \\ Compliance of Interests? The Problem of the United Germany's Borders in Polish- -French Political Relations between 1989 and 1990}

During the period of reunification of the two German states in the declining period of the Cold War, France and Poland collaborated on issues related to the reunification conditions, in particular the borders of the united Germany. France's policy was based on political calculations and was a continuation of the line taken by Paris with regard to the German issue after 1945. A certain similarity of the positions of the two states on the final shape of the borders was visible even before the beginning of the $2+4$ process. France has not withdrawn from its border declarations of the 1950s. At the crucial moment, when Germany was being reunited, it made efforts to take the voices of Germany's neighbours into account and held regular consultations with Poland.

Keywords: unification, Polish-French relations, Polish-German relations, the Cold War.

Translated by Barbara Komorowska

$62 \quad$ H. Teltschik, 329 dni..., p. 141. 